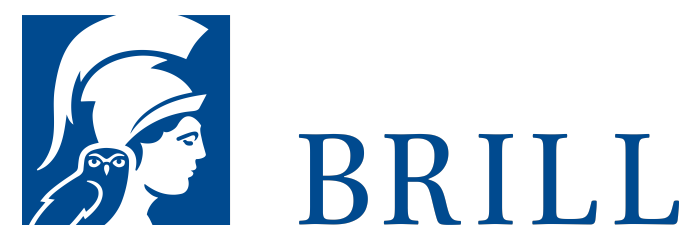

\title{
Wertebildung im Religionsunterricht
}

Grundlagen, Herausforderungen und Perspektiven

Author: Konstantin Lindner

Wertefragen haben Konjunktur. Religiöse Lern- und Bildungsprozesse können Schülerinnen und Schüler befähigen, sich ein tragfähiges Wertesystem aufzubauen.

Welche Herausforderungen bringt die »Aufgabe Werte« für Heranwachsende mit sich? Was kann schulischer Religionsunterricht im Zeitalter der Pluralität zur Wertebildung der Schülerinnen und Schüler beitragen? Ausgehend von gegenwartsgesellschaftlichen und psychologischen Diagnosen wird eine Theorie religiös grundierter Wertebildung entfaltet, die auf philosophische, soziologische sowie theologische Erkenntnisse Bezug nimmt.

Bildungstheoretischer Referenzpunkt sind dabei die Schülerinnen und Schüler, indem der Möglichkeitsraum christlich-religiöser Wertefundierung subjektorientiert erschlossen und religionsdidaktisch konturiert wird.

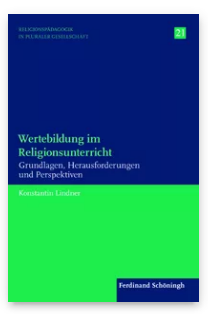

Pages: 326 Seiten, $10 \mathrm{~s} / \mathrm{w}$

Abb.

Language:

German

Subjects:

General, Theology and

World

Christianity

Publisher: Brill |

Schöningh

Series:

Religionspädagogik

in pluraler

Gesellschaft,

Volume: 21

E-Book (PDF)

Released online:

17 Nov 2017

ISBN: 978-3-

657-78554-4

List price

Paperback

Publication date:

20 Oct 2017

ISBN: 978-3-

506-78554-1

List price 
Dr. Konstantin Lindner ist Professor für Religionspädagogik und Didaktik des Religionsunterrichts am Institut für Katholische Theologie der Otto-Friedrich- Universität Bamberg.

For more information see brill.com

Order information: Order online at brill.com +44 330 333 0049 | customerservices@brill.com Submission information: brill.com/authors

Titles published by Brill | Fink, Brill | mentis or Brill | Schöningh: +49(o)71 5413279216 | brill@brocom.de 